\title{
PERSPECTIVES AND ACCENTS OF TRAINING OF THE FUTURE MASTERS IN PSYCHOLOGY FOR PROFESSIONAL ACTIVITIES IN THE CONDITIONS OF NONFORMAL EDUCATION
}

\section{Ponomarenko O. V.}

\section{INTRODUCTION}

In the early 20s of the XXI century, Ukrainian society demonstrates increasing interest in obtaining educational services in the conditions of nonformal education. Its accessibility, comfortability and individually oriented nature provides the opportunity of life-long education of all groups of the population and the empowerment of ordinary individuals due to the logistics and aesthetically attractive form of pedagogical and andragogical interaction creates a convenient and high-margin educational environment where little could be fixed and regulated.

At the same time, one of the most popular requests of the market of such services is the psychological knowledge and the practical skills that enable the most complete realization of natural potentials for each person in the reality of Ukrainian social medium. Unfortunately, owing to an almost total lack of any State and professional communities control over the subjects of such activities, people without classical psychological education and superficial understanding of the possible consequences of their commercial activity for the mental health and physical well-being of citizens appear on the market and sometimes dominate in a certain way.

This tendency is gradually changing the "rules of the game" in nonformal education in the direction of uncontrolled and unskilled charlatanry on the part of its subjects, when the purpose of "educational activities" is the maximum profit, obtained mainly on the painful problems of people, sometimes deepen mistrust of psychological science and its professionals - psychologists, psychotherapists, psychiatrists etc.

Normalization of the situation is possible by active intervention or better yet market of nonformal education services dominance of professionals in their field, their increased popularity and their productivity. 
The purpose of this subsection of the monograph is the formulation of the problem related to formation of readiness for professional activity of the future masters of Psychology in the conditions of nonformal education.

\section{Problem related to formation of readiness for professional activity of the future masters in psychology in the conditions of nonformal education}

As per List of branches of learning and specialties for which training is given for applicants of higher education in Ukraine since 2015 specialty 053 "Psychology" assigned to the branches of learning 05 "Behavioral and Social Sciences" and, in our country, the status of the future master have the persons who are enrolled in institutions of higher education by order of the head which has all the formal grounds for the organization of such training. In the academic and legislative language, the future master is a person who wishes to receive an "educational degree obtained at the second level of higher education and awarded by institutions of higher education (academic institution) as a result of a successful completion of relevant educational program by an applicant of higher education"'.

What then is the imperfection of such program in its modern traditional version and if there is, any real basis for doubt about the readiness of future masters to work effectively in the nonformal, i.e it is almost free, market of educational services?

It must be recognized that pragmatic pessimism has all the necessary methodological, theoretical, empirical and even regulatory reasons.

For example, in the regulatory aspect we are witnessing the following situation: according to article 8 of the Law of Ukraine "On education", nonformal education is acquired, in general, by educational programs and does not provide for the award of state-recognized educational qualifications by levels of education but professional and/or the award of partial educational qualifications may be granted at the end ${ }^{2}$.

1 Про затвердження переліку галузей знань і спеціальностей, за якими здійснюється підготовка здобувачів вищої освіти : постанова кабінету міністрів України від 29.04.2015 р. № 266. URL: https://zakon.rada.gov.ua/laws/show/266-2015$\%$ D0\%BF (дата звернення: 21.08.2018)

Про освіту: Закон України від 05.09.2017 p. № 2145-VIII. URL: https://zakon.rada.gov.ua/laws/show/2145-19 (дата звернення: 21.08.2018) 
Thus, at the legislative level, nonformal, and, hence, uncontrollable in fact by anyone, including the State, education has right not only to acquire to anybody and any education, but, in some cases, to receive partial educational and professional qualifications. At the same time, the only criterion (measure) of the quality of such activities is the demand of the population. There is nothing to discuss of what kind of mass manipulations subjects of psychological and pedagogical activity in the market of nonformal educational services can resort, because psychological and pedagogical Sciences are not STEM, which means the insufficiency of knowledge of mankind, their dialectical nature and the complexity of the objective operationalization of the results of such education.

In particular, as was known, the representatives of psychological science, the developers of its philosophical and methodological principles, have built an ambiguous theoretical foundation, sometimes proven by prolonged large-scale experiments, confirmed by reliable empirical results, and sometimes existing only in the imagination of the authors as an abstract idea that explains successfully the social and individual behavior and human nature.

For example, among the most influential and respected founders of psychological science, whose thoughts are now meaningful basis of University textbooks of practical psychology, it must be recognised almost indefinite polyvariability of theoretical positions (A. Adler, W. James, E. Erickson, S. Kierkegor, A. Maslow, R. May, B. Reich, K. Rogers, B. Skinner, V. Frankl, Z. Freud, E. Frohm, K. Jung etc.) ${ }^{3}$.

The authors had tried to determine the essence of human life and its motive power, trying to "present" to the society the universal technology to ensure a happy and productive life. At the same time, the understanding of humanity in each individual scientific school was considerably different, adjusting the patterns of social relations and individual senses at a particular point of history. It is interesting that most of these scientists, especially foreign, had a considerably commercial success as psychologists-practitioners, working right in nonformal environment.

${ }^{3}$ Фейджер Р., Фейдимен Д. Личность. Теории, эксперименты, упражнения. 5-е меджунар. изд. Москва : ОЛМА-ПРЕСС, 2001. 864 с 4. Про вищу освіту : Закон України від 01.07.2014 р. № 1556-VII. URL: http://zakon2.rada.gov.ua/laws/show/155618 (дата звернення: 21.08.2018) 
The comparative analysis of the theoretical generalizations which left behind them gives the chance to make sure that psychological science in the fundamental plan is enough far from complete of construction of own theory that would meet the representatives of all existing recognized scientific schools. The diversity of behavioristic, humanistic, cognitive, transpersonal, religious, logotherapeutic and other concepts confirmed that.

It must be said that modern scientists are well ahead of their predecessors by level of intensity and quantitative objectives despite the fact that psychology, as a science, remained open on the issue of its subject by keeping the ordinary professional - graduate of institutions of higher education, among the many subjective and non-sufficient generalizations that do not allow full trust of itself as an expert nor any scientific school or paradigm, in principle.

Meanwhile, such critical observations do not reduce the role and importance of the scientific generalizations received to date of scientists who continue the hard way of conceptual and experimental work, trying to obtain universal laws and regularities of the existence of the human psyche in conditions when even the definition of the term "psyche" is ambiguous in each individual scientific subculture.

This problem has in many cases been the reason for situation when the majority of young professional psychologists, understanding the complexity and responsibility for the results of their professional activities in conditions of nonformal education, often abandon the practice of large-scale activities in nonformal education of the population completely in favor of well-tested and proven models of client's individual counseling which generally resembles the classic "revolutionary situation" when professionals can't yet work "in a new way" and the population does not want to receive educational services "as before" - that is in traditional universities and other formal educational institutions.

Of these obvious reasons it is necessary exactly to review certain aspects of professional education of psychologists, namely in the context of the formation of the readiness of future specialists in the field of mental health for responsible and effective competitive activity in nonformal education.

In favour of the importance of this task evidenced and advocated by the powerful democratic processes in society that has finally touched the 
sphere of real education. The Laws of Ukraine "On higher education" $(2015)^{4}$, "On education" (2017) $)^{5}$, the Concept of the new Ukrainian school $(2017)^{6}$; the National Policy for the Development of Education ${ }^{7}$ and other legal and ideological documents demonstrate not only the tendency for the population to choose more freely educational programs and institutions provide general, vocational or higher education but also the promotion and recognition of nonformal education as an important part of the system as a whole.

These documents with their content have expanded the opportunities for freedom of every individual, have become an important factor in optimizing the activities of the nonformal educational sphere of Ukraine, bringing the moment when adequate requirements for its quality will be put forward and the initiative of all its subjects will also increase with responsibility for the education of the population during life.

The defined problematics was the subject of studies of number of humanitarian nature sciences that considered nonformal education of the population and professional education of future psychologists from different perspectives and from different points of view - psychological, pedagogical, sociological etc. At the same time, the basic conclusions and generalizations of scientists lived often together peacefully in framework of dissertation ideas but encountered aggressively in practice, demonstrating too weak linkages to it. In particular, in the Ukrainian scientific discourse on professional education of future psychologists, we are even witnessing the certain competition between two scientific specialties that overlapped and complemented each other: 19.00.07 pedagogical and developmental psychology and 13.00.04 - theory and methodology of professional education.

${ }^{4}$ Про вищу освіту: Закон України від 01.07.2014 p. № 1556-VII. URL: http://zakon2.rada.gov.ua/ laws/show/1556-18 (дата звернення: 21.08.2018)

${ }^{5}$ Про освіту : Закон України від 05.09.2017 р. № 2145-VIII. URL: https://zakon.rada.gov.ua/ laws/show/2145-19 (дата звернення: 21.08.2018)

${ }^{6}$ Про схвалення Концепції реалізації державної політики у сфері реформування загальної середньої освіти «Нова українська школа» на період до 2029 року : розпорядження Кабінету Міністрів України від 14.12.2016 p. №988-p. URL: https://zakon.rada.gov.ua/laws/show/988-2016-\%D1\%80\#n8 (дата звернення: 21.07.2018)

${ }^{7}$ Національна доктрина розвитку освіти. URL: https://zakon4.rada.gov.ua/ laws/show/347/2002 (дата звернення: 21.08.2018) 
The first is presented by scientists who consider the sources, motive power, psychological mechanisms and regularities of formation and development of the personality of future psychologists, by focusing usually on the themes of their intellectual and emotional growth in the learning process, the regularities of learning by subjects of psychological practice of the necessary knowledge, skills, development of motives for professional self-realization etc ${ }^{8}$.

The second scientific specialty explores the purposes, content, methods, organizational forms and means of professional education of future psychologists, focusing on the issues of theoretical and methodological nature, the development of standards, models and pedagogical technologies, the search for meaningful innovations in vocational education on both at the level of teaching certain disciplines of professionally-oriented cycles, the development of highquality educational and methodological support and at the level of organization of field attachment, manufacturing and educational practices.

Analysis of academic publications, electronic resources of the National Academy of pedagogical Sciences of Ukraine $^{9}$ led to the identification the directions of research that were held in Ukraine over the last 10-15 years and included professional training of future psychologists. It is impossible into one article to even list all aspects of the development of professional competence of this category of specialists but we will name some objects of research, in particular: the development of professional motivation and identity (values-based orientations and value-semantic sphere T.A. Viluzhanina ${ }^{10}$, personal maturity of future psychologists

${ }^{8}$ Паспорт спеціальності 19.00.07: педагогічна та вікова психологія: [електронний ресурс]. Режим доступу: https://www.pdpu.edu.ua/nauka/180naukova-diyalnist/spetsializovani-vcheni-radi/spetsializovana-vchena-rada-d-41-05303/chleni-radi-ta-pasporti-spetsialnosti/810-pasport-spetsialnosti-19-00-07pedagogichna-ta-vikova-psikhologiya (дата звернення 10.08.2018 р.)

9 Протоколи міжвідомчої ради НАПН України 3 питань координації наукових досліджень в галузі педагогіки та психології URL: http://naps.gov.ua/ua/iccr/protocols/ (дата звернення: 21.07.2018).

10 Вилюжанина Т. А. Динамика образа “Я” студентов-психологов // Теоретико-методологічні проблеми генетичної психології: Матеріали Міжнародної наукової конференції, присвяченої 35-річчю наукової та педагогічної діяльності академіка С. Д. Максименка. Київ, 2002. С. 46-49. 


\section{N. M. Didik ${ }^{11}$, I.A. Druzhinina ${ }^{12}$, professional thinking T.E. Gura ${ }^{13}$}

etc.

Unfortunately, the diversity and large number of studies for the training of future psychologists was too slow transformed into a high quality of their professional activities, especially in the market of nonformal educational services that a combination gives opportunity to declare as a progressive and relevant the next scientific idea - the development of the author's version of training for professional activities of future masters of psychology in the conditions of nonformal education.

Its perspective viability is confirmed that there was, in the theory and practice of professional education of masters of psychology, contradiction between:

- objective requirement of society in highly professional masters of psychological education of the population in the conditions of nonformal education which would in harmony combine in their nature the high level of professional and pedagogical competences and insufficient level of theoretical and methodical base for development of such skill in institutions of higher education;

- understanding of specificities of professional activity of psychologists in the conditions of nonformal education and insufficient level of density of process of professional education by adequate means and methods of quasi-professional character;

- requirement to introduce individualized technologies of the development of readiness for professional activity in nonformal education and the use of standardized tools and methods of

11 Дідик Н. М. Дослідження професійно значущих характеристик особистісної зрілості майбутніх психологів. Проблеми сучасної психології. 2014. Вип. 23. С. 160 170. Режим доступу: http://nbuv.gov.ua/UJRN/Pspl_2014_23_16 (дата звернення: 21.08.2018).

12 Дружиніна I. А. Розвиток професійної ідентичності майбутніх практичних психологів засобами активного соціально-психологічного навчання. Актуальні проблеми психології : зб. наук. пр. нституту психології ім. Г. С. Костюка АПН України / за ред. С. Д. Максименка, М. В. Папучі. - Київ-Ніжин : Видавництво НДУ; ДС "Міланік", 2007. - Т. 10, Вип. 1. - С. 74-76.

${ }^{13}$ Гура Т. Є. Психологічні закономірності, механізми та принципи розвитку професійного мислення у майбутніх психологів у процесі фахової підготовки. Науковий часопис НПУ імені М. П. Драгоманова. Серія 19 : Корекційна педагогіка та спеціальна психологія. 2014. Вип. 25. - С. 266-272. - Режим доступу: http://nbuv.gov.ua/UJRN/Nchnpu_019_2014_25_37 (дата звернення: 21.08.2018) 
professional education of future psychologists which block the improvement of their qualifications.

The wish to eliminate the presented contradictions by optimal use of pedagogical reserves of institutions of higher education, determines the necessity of theoretical justification and empirical validation of the defined concept of the readiness formation of future masters in psychology for professional activity in the conditions of nonformal education. It led us to the choice of relevant themes of the dissertation "Theoretical and methodological backgrounds to train the future masters in psychology for professional activities in the conditions of nonformal education".

The purpose of this study is to justify the theoretical and methodological backgrounds to train the future masters in psychology for professional activities in the conditions of nonformal education.

At the level of previous, intuitively appealing forecasts at this stage of the study, we have only projects of general and partial hypotheses.

Thus, the general hypothesis is based on the assumption that the preparation of future masters in the specialty 053 "Psychology" in institutions of higher education will be more effective in the context of the formation of students ' readiness for professional activity in nonformal education, if it is implemented according to the developed theoretical and methodological backgrounds of the pedagogical process, the meaningful basis of which will be the author's concept and pedagogical technology that will find its objectivization and detalization in partial hypotheses, according to which:

- project-purposeful cluster will be based on the understanding of readiness for professional activity in the conditions of nonformal education as an integrative professional quality that provide to achieve promising private purposes and meanings in the market of nonformal educational services without excessive psychophysiological, intellectual and emotional stresses and strains and with minimal loss of time and finance. At the same time, the efficient parameters of the designated quality should be based, on the existing social demand, on the one hand, and on the other - on the need of the future masters of psychology in professional and personal self-realization;

- procedural cluster of formation of readiness for professional activity of future masters of psychology in the conditions of nonformal education reflects the adequate picture of full-time and 
remote interaction of subjects of the andragogical process, during which it's continuing: to determine the level of readiness for professional activity in the conditions of nonformal education and to provide the initial recommendations on the development of this professional quality based on the results of this procedure; to build personal "startups" to enter the market of nonformal educational services and to construct individual trajectories of development of relevant competencies on the basis of established behavioral, internalreflective and intellectual characteristics of the human, the degree of his personal motivation, as well as analysis of difficulties which it faced at the time of training pedagogical and psychological practice;

- efficient cluster of formation of readiness for professional activity of future masters of psychology in the conditions of nonformal education materialize via access to autonomous cognitive interests of students which ensure full subjectivity of professionals in the choice of options of self-identification and self-realization, intensive study of the nature of actual educational services.

\section{The contradiction and complexity of nonformal education as a platform for professional self-realization of specialists in psychology}

As previously stated, among the priority tendencies of the development of education in Ukraine in the XXI century, the processes conducive to satisfying any educational needs of citizens in nonformal way become important.

At the same time, the study of the content of such requests demonstrates a significant increase in the demand for psychological knowledge and elementary competencies of citizens of Ukraine, which confirms the need to form the readiness of present and future professional psychologists to various activities in nonformal education. Among the main contradictions which is the substantive basis of this problem - the contradiction between the obvious need to concentrate training courses for improve the competitiveness of future psychologists in the market of nonformal education and superficial understanding of the essential characteristics of students' readiness in educational programs for professional self-realization in unpredictable conditions of this environment, low understanding level of the nature of difficulties 
which are awaiting graduates-psychologists who want to materialize their competencies in conditions of nonformal education.

It is true that the modern world requires the majority of specialists of permanent professional competitiveness and in terms of professional activity of the psychologist in the market of nonformal education, this quality is the main measure of the effectiveness of professional education.

In the scientific and pedagogical discourse, the phenomenon of nonformal education is unpopular and the study in this area is significantly inferior in the number of scientific publications and defended dissertations. Analysis of the content of the protocols of the inter-agency Coordinating Council for the scientific research in the field of pedagogy and psychology of the National Academy of Pedagogical Sciences of Ukraine indicates that, over the last seventeen years, the authors of Ph.D. and doctoral dissertations have chosen themes, directly or indirectly related to nonformal education, only 51 times!

Most of the works are devoted to the study of general tendencies in the development and organizational and pedagogical foundations of nonformal education in various countries of the world, namely Sweden (V. D. Davydova, U.Y. Derkach, M. I.Kolodко), Germany (O. V. Zunkina, V. M. Soloshchenko), UK (Sesay Mohamed ), Belgium (O. V. Zakrevska), Czech Republic (V. V. Strizhalkovska), USA (N.O. Terekhin, O. V. Vasilenko), Canada (U. I. Shustak), Finland (I.V. Meleshko), Belarus (O. A. Isaeva), Ukraine (L. I. Vashchenko, O. L. Samodumska, L. I. Bryn $)^{14}$.

One of the few scientists who the closest come to the problem for the training of humanitarian professionals to work in conditions of nonformal education, can be called V. Kabatska who has chosen to study the theme of formation of readiness of charity workers to provide educational services in the context of nonformal education, O. Polivka who concentrate discussion on the process of training of future teachers of expressive arts to training of the pupils of folk arts in conditions of nonformal education and O. Samodumska, the development of the theoretical and methodological backgrounds of training of future

14 Самодумська О.Л. Підготовка науково-педагогічних працівників до діяльності у неформальній освіті дорослих: реалії та перспективи : збірник наукових праць. Вісник Житомирського державного університету ім. І. Франка : зб. наук. пр. [редкол.: П. Ю. Саух (голов. ред.) та ін.]. Житомир, 2018. Вип. 4 (95). 
andragogists in adult education in conditions of nonformal education became objective of her scientific activity.

At the same time, scientists have not yet been able to complete their research and, judging by leave the "marks " in open sources, they are still at the stage of pilot pedagogical experiments and at the formation of methodological and theoretical basis for further scientific activity.

Nevertheless, O. Samodumska already presented to the public the justification of the severity and urgency for problem of training of future or existing andragogists to adult education in conditions of nonformal education. The author singles out some contradictions in the pedagogical processes of higher education, presents preliminary hypotheses of the formative work, carried out the formulation of the problem in general terms etc. The author confirms the opinion that the purpose of nonformal education is the realization of the human right to life-long education, its active inclusion in professional and public life through obtaining the necessary and efficient appropriate educational services. Such services, according to O. Samodumska, are provided by groups of citizens at different levels-national, confessional, professional or otherwise, corporate entities, private individuals and their families that have the legal right to provide such educational services in Ukraine. Basic education and the qualifications of service providers of adult nonformal education are often inadequate to the requirements associated with teachers and educationalists in formal education institutions.

The authors have reviewed and brought forward the foreign experience for regularization of nonformal education, described its pros and cons, the essence and methodological basis, characterized the organizational and procedural conditions for its functioning, the mechanisms of state support, the ways of using of civic initiative, the dominant requests and the most popular forms and methods of their implementation. At the same time, we have not found substantive achievements of pedagogical science in the aspect of correction of professional education of specialists in psychology associated with intensive development of the market of nonformal education.

The purpose of this paragraph of the monograph is to highlight the perspectives and difficulties of training of future psychologists for professional activities in conditions of nonformal education.

In people's everyday experience, nonformal education is provided as education options for the population that is not culminating in the qualification, formal recognition of competencies or professional skills. 
The Law of Ukraine "On education" defines nonformal education as such, which "is usually acquired by educational programs and does not provide the award of state-recognized educational qualifications by level of education but may culminating with the assignment of professional and/or the award of partial educational qualifications".

It is obvious that the main characteristic of nonformal education according to this definition is that it is an alternative application to formal education in the process of human life-long education and it is being implemented in order to guarantee the right to free access to education in convenient way and in comfortable conditions.

The society, at a certain stage of development of nonformal education, has decided that it provides the opportunity to obtain qualifications but the persons, who obtained it, are not officially recognized as specialists according to the existing standards of recognition by national education authorities.

Such a state of affairs is being adjusted progressively by the circumstances of objective reality that requires an absolutely adequate recognition of person's competence without any consideration for his formal education. Naturally, when in the world the lectures and public discussions of the majority of Nobel laureates are at free access, when many universities and colleges provide to use at no cost of the content developed by scientific and pedagogical workers - the right of academic education to a monopoly on the recognition of professional qualifications is gradually becoming nonsense.

Already today in Ukraine, subjects of recognition of qualification are approved (alack a day, still at the level of working professions ${ }^{15}$, list of working professions for which formally recognized qualifications is provided $^{16}$.

It is obvious that this process will continue to receive the support of civil society which requires transparency and pragmatism in matters of development of the educational sphere, the withdrawal of the so called "Soviet type of thinking", one of the major weaknesses of which was the

15 Про внесення змін до Переліку суб'єктів підтвердження результатів неформального професійного навчання осіб за робітничими професіями : Наказ $\mathrm{MOH}$ України № 466 від 03.04.2018. URL: https://zakon.rada.gov.ua/laws/show/z0491-18

${ }^{16}$ Про внесення змін до Переліку робітничих професій, за якими здійснюється підтвердження результатів неформального професійного навчання осіб за робітничими професіями : Наказ МОН України № 783 від 13.05.2017 URL: https://zakon.rada.gov.ua/laws/show/z0665-17. (дата звернення: 21.08.2018) 
cross-regulation of most of the procedures and stages of education, the presence of a system of control over compliance with the formal signs of the quality of the organization of educational processes etc.

As opposed to this Soviet tradition, other system of values are at the top of the agenda, in particular setting on academic freedom, in Article 1. of the Law of Ukraine "On education" ' shall mean the selfdependence and the independence of the participants of the educational process during the implementation of pedagogical, scientificpedagogical, scientific and/or innovative activities which carried out on the principles of freedom of speech, cogitations and creativity, dissemination of knowledge and information, free disclosure and use of the results of scientific research taking into account the restrictions, established by law.

The last sentence of the article on "taking into account the restrictions, established by law" is a key difficulty for all subjects of pedagogical and administrative processes because it requires them clear understanding of the existing legislative and regulatory restrictions in their pedagogical creativity.

At the same time, most of the possible restrictions are practically smooth away in the conditions of nonformal education any pressure from the quality of educational services control authorities, on the one hand, and on the other - by placing customers outside the protection from poor quality services or immodest charlatanism. Such services have a particularly strong presence in the "pedagogical" activities of "specialists" in finance and psychology.

Among the examples of such abuse it can be cited intense, vivid and strong advertising supply on the market of nonformal education which propose to present to clients "therapy of sacred alignment", "mental cleaning", "astral settings" etc.

These and other innumerable examples proved that the modern market of nonformal education is indeed characterized by the lack of any control over the subjects of educational services in which the people without classical psychological education and superficial understanding of the possible consequences of their commercial activity for the mental health and physical well-being of citizens appear and sometimes dominate in a certain way. At the same time, the possibility of the most complete embodiment of the potentials of graduates is observed in nonformal educational services areas where the necessary 
conditions were spontaneously or purposefully created for the financial and social success of professionals in the sector.

Examples of making of successfully personal "startups" of market entry and designing of individual trajectories of development of individual professionals in the field of behavioural sciences allow to predict a further increase in the interest of graduates with master's degrees in psychology and expanding the range of services and themes of interaction with potential customers through the establishment of their behavioral, internal-reflective and intellectual needs, actual motives for ordering services, overcoming the difficulties of personal and professional life through psychological support etc.

The included monitoring of the peculiar workings of psychologists in the conditions of nonformal education in its modern version allows to explicate the following important characteristics: accessibility, comfort, personality-oriented character, logistic and aesthetic appeal of forms of pedagogical and andragogical interaction. At the same time, psychological knowledge and practical skills are one of the most popular requests that enable the most complete realization of natural potencies of each person in the reality of Ukrainian society.

Among the negative circumstances of existence of market of nonformal psychological and educational services - uncontrolled and sometimes low-skill "service" and sometimes charlatanism on the part of its subjects when the purpose of "educational activities" is the maximum profit obtained largely from the painful problems of people. It does make the distrust of psychological science and its professionals-psychologists, psychotherapists, psychiatrists etc.

Normalization of the situation, we believe, is possible by active intervention or better yet market of nonformal education services dominance of professionals in their field, their increased popularity and their productivity.

We shall note, that the majority of young professional psychologists, understanding the complexity and responsibility for the results of their professional activities in conditions of nonformal education, often abandon the practice of large-scale activities in nonformal education of the population completely in favor of well-tested and proven models of client's individual counseling which generally resembles the classic "revolutionary situation" when professionals can't yet work "in a new way" and the population does not want to receive 
educational services "as before" - that is in traditional universities and other formal educational institutions.

In favor to remedy such shortcomings advocated by the strong democratic processes in society, that has finally touched the sphere of real education.

The Laws of Ukraine "On higher education" (2015), "On education" (2017), the Concept of the new Ukrainian school (2017); the National Policy for the Development of Education and other legal and ideological documents demonstrate not only the tendency for the population to choose more freely educational programs and institutions provide general, vocational or higher education but also the promotion and recognition of nonformal education as an important part of the system as a whole.

These documents with their content have expanded the opportunities for freedom of every individual, have become an important factor in optimizing the activities of the nonformal educational sphere of Ukraine, bringing the moment when adequate requirements for its quality will be put forward and the initiative of all its subjects will also increase with responsibility for the education of the population during life.

\section{CONCLUSIONS}

The arguments presented in the article prove the currently forwardlooking of scientific research of the problem of professional training of future masters in psychology for professional activity in the conditions of nonformal education.

Concrete definition of shortcomings and empirical characteristics of the traditional pedagogical process in higher education institutions, search and justification of indicators of readiness said specialists to work successfully in circumstances of uncertain nature need to be further addressed.

Identification and highlighting of the more popular and better ways of nonformal educational business which potentially includes psychological and pedagogical services of future masters of psychology is also the significant problem.

Forward-looking theme for addressing is the analytical work on the content of the most constructive proposals of Ukrainian and worldwide researchers of the problem, looking for ideas to extrapolation from related sectors and areas in which the issue of increasing the competitive 
advantages of specialists in the market of nonformal educational services has become the subject of research or empirical success.

The defined problematics was the subject of related attention of a number of humanitarian nature scientists that considered nonformal education of the population and professional education of future educationalists and teachers from different perspectives and from different points of view - psychological, pedagogical, sociological etc. At the same time, the basic conclusions and generalizations of scientists lived often together peacefully in framework of dissertation ideas but encountered aggressively in practice, demonstrating too weak linkages to it. In particular, in the Ukrainian scientific discourse on nonformal education at the level of previous, intuitively appealing forecasts at this stage of the study, we have only projects of general and partial hypotheses.

Perspective for further study is: identification and highlighting of the more popular and better ways of nonformal educational business which potentially includes psychological and pedagogical services of future masters of psychology is also the significant problem; analytical work on the content of the most constructive proposals of Ukrainian and worldwide researchers of the problem; looking for ideas to extrapolation from related sectors and areas in which the issue of increasing the competitive advantages of specialists in the market of nonformal educational services has become the subject of research or empirical success.

\section{SUMMARY}

The article deals with perspectives and accents of training of the future masters in psychology for professional activities in the conditions nonformal education

The article emphases one of the most popular requests of the market - psychological knowledge and the practical skills that enable the most complete realization of natural potentials for each person in the reality of Ukrainian social medium. Unfortunately, owing to an almost total lack of any State and professional communities control over the subjects of such activities, people without classical psychological education and superficial understanding of the possible consequences of their commercial activity for the mental health and physical well-being of citizens appear on the market and sometimes dominate in a certain way. 
Thus, the general hypothesis is based on the assumption that the preparation of future masters in the specialty 053 "Psychology" in institutions of higher education will be more effective in the context of the formation of students ' readiness for professional activity in nonformal education, if it is implemented according to the developed theoretical and methodological backgrounds of the pedagogical process, the meaningful basis of which will be the author's concept and pedagogical technology that will find its objectivization and detalization in partial hypotheses

Perspective for further study is: identification and highlighting of the more popular and better ways of nonformal educational business which potentially includes psychological and pedagogical services of future masters of psychology is also the significant problem; analytical work on the content of the most constructive proposals of Ukrainian and worldwide researchers of the problem; looking for ideas to extrapolation from related sectors and areas in which the issue of increasing the competitive advantages of specialists in the market of nonformal educational services has become the subject of research or empirical success.

\section{REFERENCES}

1. Про затвердження переліку галузей знань і спеціальностей, за якими здійснюється підготовка здобувачів вищої освіти : постанова кабінету міністрів України від 29.04.2015 р. № 266. URL: https://zakon.rada.gov.ua/laws/show/266-2015-\%D0\%BF (дата звернення: 21.08.2018).

2. Про освіту : Закон України від 05.09.2017 р. № 2145-VIII. URL: https://zakon.rada.gov.ua/laws/show/2145-19 (дата звернення: 21.08.2018)

3. Фейджер Р., Фейдимен Д. Личность. Теории, эксперименты, упражнения. 5-е меджунар. изд. Москва: ОЛМА-ПРЕСС, 2001. $864 \mathrm{c}$

4. Про вищу освіту: Закон України від 01.07.2014 p. № 1556-VII. URL: http://zakon2.rada.gov.ua/laws/show/1556-18 (дата звернення: 21.08.2018).

5. Про освіту : Закон України від 05.09.2017 р. № 2145-VIII. URL: https://zakon.rada.gov.ua/laws/show/2145-19 (дата звернення: 21.08.2018) 
6. Про схвалення Концепції реалізації державної політики у сфері реформування загальної середньої освіти «Нова українська школа» на період до 2029 року : розпорядження Кабінету Міністрів України від 14.12.2016 p. №988-p. URL: https://zakon.rada.gov.ua/ laws/show/988-2016-\%D1\%80\#n8 (дата звернення: 21.07.2018).

7. Національна доктрина розвитку освіти. URL: https://zakon4.rada.gov.ua/laws/show/347/2002 (дата звернення: 21.08.2018).

8. Паспорт спеціальності 19.00.07: педагогічна та вікова психологія: [Електронний ресурс]. Режим доступу: https://www.pdpu.edu.ua/nauka/180-naukova-diyalnist/spetsializovanivcheni-radi/spetsializovana-vchena-rada-d-41-053-03/chleni-radi-tapasporti-spetsialnosti/810-pasport-spetsialnosti-19-00-07-pedagogichnata-vikova-psikhologiya (дата звернення 10.08.2018 p.)

9. Протоколи міжвідомчої ради НАПН України 3 питань координації наукових досліджень в галузі педагогіки та психології URL: http://naps.gov.ua/ua/iccr/protocols/ (дата звернення: 21.07.2018).

10. Вилюжанина Т. А. Динамика образа “Я” студентовпсихологов // Теоретико-методологічні проблеми генетичної психології: Матеріали Міжнародної наукової конференції, присвяченої 35-річчю наукової та педагогічної діяльності академіка С. Д. Максименка. Київ, 2002. С. 46-49.

11. Дідик Н. М. Дослідження професійно значущих характеристик особистісної зрілості майбутніх психологів. Проблеми сучасної психології. 2014. Вип. 23. С. 160-170. Режим доступу: http://nbuv.gov.ua/UJRN/Pspl_2014_23_16 (дата звернення: 21.08.2018).

12. Дружиніна I. А. Розвиток професійної ідентичності майбутніх практичних психологів засобами активного соціальнопсихологічного навчання. Актуальні проблеми психології : зб. наук. пр. нституту психології ім. Г. С. Костюка АПН України / за ред. С. Д. Максименка, М. В. Папучі. - Київ-Ніжин : Видавництво НДУ; ДС "Міланік", 2007. - Т. 10, Вип. 1. - С. 74.

13. Гура Т. С. Психологічні закономірності, механізми та принципи розвитку професійного мислення у майбутніх психологів у процесі фахової підготовки. Науковий часопис НПУ імені М. П. Драгоманова. Серія 19 : Корекційна педагогіка та спеціальна 
психологія. 2014. Вип. 25. - С. 266-272. - Режим доступу: http://nbuv.gov.ua/UJRN/Nchnpu_019_2014_25_37.

14. Самодумська О. Л. Підготовка науково-педагогічних працівників до діяльності у неформальній освіті дорослих: реалії та перспективи : збірник наукових праць. Вісник Житомирського державного університету ім. І. Франка : зб. наук. пр. [редкол.: П. Ю. Саух (голов. ред.) та ін.]. Житомир, 2018. Вип. 4 (95).

15. Про внесення змін до Переліку суб'єктів підтвердження результатів неформального професійного навчання осіб за робітничими професіями : Наказ $\mathrm{MOH}$ України № 466 від 03.04.2018. URL: https://zakon.rada.gov.ua/laws/show/z0491-18

16. Про внесення змін до Переліку робітничих професій, за якими здійснюється підтвердження результатів неформального професійного навчання осіб за робітничими професіями : Наказ MOH України № 783 від 13.05.2017 URL: https://zakon.rada.gov.ua/ laws/show/z0665-17. (дата звернення: 21.08.2018).

\section{Information about the author:} Ponomarenko O. V.

Doctor of Philosophy, Associate Professor, Dean of Faculty of Social Pedagogy and Psychology, Zaporizhzhia National University 66, Zhukovsky str., Zaporizhzhia, 69000, Ukraine 